\title{
MAGYAR KÖZÉPISKOLÁS KORÚ FIATALOK TÁPLÁLKOZÁSI SZOKÁSAI ÉS HÁTTÉRTÉNYEZŐI
}

\author{
AN ANALYSIS OF NUTRITIONAL HABITS AMONG YOUNG HUNGARIAN ADOLESCENTS \\ Kárai Brigitta, Hidvégi Péter
}

Debreceni Egyetem, Sporttudományi Koordinációs Intézet, Debrecen

\section{Összefoglaló}

Magyarországon az egészségtelen életmódon belül a helytelen táplálkozás az egyik fó oka a magas megbetegedési és halálozási aránynak. Ezek az attitüdök legtöbb esetben már gyermekkorban kialakulnak, ezért is fontos a gyermekek megfelelö táplálkozása és az egészséges életmódra nevelése. Az étkezések mennyisége és minősége befolyásolja a növekedést, fejlődést, valamint a jövőbeni egészségi állapotukat is. A szív-és érrendszeri betegségek, magas vérnyomás, cukorbetegség, valamint számos daganatos betegség kialakulásában jelentős szerepet játszanak a helytelen táplálkozási szokások. Célom, hogy feltárjam azokat a területeket, ahol leginkább elérhetőek a diákok és prevenciós programok segítségével csökkenthető lenne az elhízott fiatalok és ezzel együtt a későbbiekben az elhízott felnôttek aránya is.

Kulcsszavak: táplálkozási szokások, elhízás, kortárshatások, közösségi média, család

\section{Abstract}

In Hungary, malnutrition within the unhealthy lifestyle is one of the main reasons for the high morbidity and mortality rate. In most cases, these attitudes develop in childhood; that is why it is important to feed children properly and educate them to lead a healthy lifestyle. The quantity and quality of meals also affect growth, development, and future health. Improper eating habits play a significant role in developing cardiovascular disease, hypertension, diabetes, and many cancers. Our goal is to explore the areas where students are most accessible, and prevention programs could reduce the proportion of obese youth, and at the same time, obese adults in the future.

Keywords: nutritional habits, obesity, family, social media, contemporary influences 


\section{ELMÉLETI HÁTTÉR}

Hazánkban népbetegségnek számít az elhízás és az ebből eredő betegségek, úgy, mint a magas vérnyomás, cukorbetegség, daganatos megbetegedések. Már a gyermekek és serdülők körében is komoly problémát okoz a korai elhízás. Bizonyított a tény, hogy elhízott gyermekekből nagyobb eséllyel lesz elhízott felnőtt, valamint sok betegség kialakulásában is szerepet játszik a gyermekkori súlyfelesleg. A fejlett országokban a túlsúlyos vagy elhízott gyermekek és felnőttek száma arányosan növekszik a kettes típusú diabétesszel diagnosztizáltak számával. (KSH, 2015) Az elhízás a helytelen táplálkozási szokások és/vagy az inaktív életmód következménye. Fontos, hogy a gyermekek megfelelő mennyiségű és minőségű tápanyagot vigyenek be a szervezetükbe, nap, mint nap. Ez hozzájárul az optimális fejlődésükhöz, növekedésükhöz és testi- lelki jóllétükhöz. A fiatalok táplálkozását elsősorban a primer szocializációs közeg, a család határozza meg, óvodás, iskolás korban a szekunder szocializációs közeg és serdülő korban egyre inkább a kortársaknak és a közösségi médiában látottaknak van befolyásoló hatása.

\section{A kutatás célkitüzése}

Jelen kutatás célja, hogy feltárjuk a fiatalok életmódbeli veszélyeztetettségét, háttér információkat gyűjtve az egészségi állapotukat befolyásoló táplálkozási tényezőkről. A jövőben a kérdőíves adatok tükrében pedig feltérképezzük a különböző prevenciós beavatkozási területeket.

\section{MÓDSZER}

Jelen kutatásban szakirodalmi feltárást végeztem a téma szempontjából, releváns szakirodalomból.

\section{EREDMÉNYEK}

\section{SZOCIÁLIS TÉNYEZŐK}

Elfogadott tény, hogy a csecsemőtáplálásnak az első 1000 napban hosszú távú hatásai lehetnek a gyermek későbbi egészségére. „A legalább négy hónapig tartó kizárólagos szoptatás fontos szerepet játszik a gyermekkori elhízás kockázatának csökkentésében” (SÁGODI et al., 2017). Gyermekkorban a szülők feladata az egészséges ételek és a közös családi étkezések biztosítása. Manapság nagyon nehéz dolga van annak az anyukának vagy apukának, aki egyszerre asztalhoz szeretné ültetni a családot nap, mint nap. Minél nagyobbak a gyerekek, ezt annál nehezebb megvalósítani, pedig a család minden tagjának előnyös volna a gyakori közös étkezés. A felnőttek részéről ez a reggeltől késő estig tartó munka, esetleg több munkahely miatt aligha kivitelezhető. Ebben a rohanó világban nincs idő napközben sem leülni és egészséges főtt ételt enni. 


\section{MÁSODLAGOS SZOCIALIZÁCIÓS KÖZEG, AZ ISKOLA}

A gyermekek oldaláról nézve, ők egész nap iskolában vannak, gyakran délutánig. Jobb esteben van egy hosszabb szünet az óráik között, amikor ebédelni tudnak. Általános iskolában az esetek nagytöbbségében menza is müködik és lehetőségük van a gyermekeknek ebédidőben két fogásos (leves, második) főtt ételt enniük. Középiskolában gyakori a napi 7-8 tanítási óra, amelyek között jó, ha van annyi idő, hogy a diákok eljussanak mosdóba. Ha van idejük enni, akkor sincs annyi, hogy hazamenjenek (főleg, ha kollégiumban laknak) vagy elmenjenek a menzára ebédelni. Egy 2004 és 2005 között végzett kutatás alapján, nagyon alacsony az iskolai étkezésben résztvevők száma $(12,4 \%)$ a középiskolások körében. (KAPOSVÁRI, 2007) Így vagy visznek magukkal „ebédet”, vagy vesznek valamit az iskolabüfében. Véleményem szerint ritka az olyan büfé, ahol lehet egészséges ételt, gyümölcsöt vagy zöldséget kapni, gyakoribb a péksütemény és a szendvics. A diákoknak leginkább akkor van lehetőségük zöldséget és gyümölcsöt fogyasztani, ha visznek magukkal az iskolába.

A tanítási órák után hazaérve, délután 2-3 óra körül a fejlődésben lévő serdülőkorú diákok, már valószínűleg éhesek. Ha otthon nincs a szülők által főzött étel, akkor nagy valószínűséggel gyorsételt, valamilyen „snacket”, vagy édességet fognak enni a gyerekek. Manapság egyre gyakoribb az ételrendelés, amely a fiatalkorúak körében is megfigyelhető. Neumark-Sztainer és munkatársai fókuszcsoportos felmérést végeztek a középiskoláskorúak (15-19 évesek) körében, azzal kapcsolatban, hogy mi befolyásolja az ételválasztási preferenciájukat. Eredményül azt kapták, hogy a serdülők az étel kinézetét, az ízét, a kényelmet és az időfaktort, (azaz mennyi időbe telik hozzájutni vagy elkészíteni) és olyan célokat, mint az elhízás elkerülése és a soványság, emelték ki. Tehát sokkal inkább választanak egy olyan ételt, amit házhoz rendelnek, vagy egy étteremben ülve hamar megkapnak, mint egy hosszú elkészítési időt igénylő egészséges ételt. (NEUMARKSZTAINER et al., 1999)

\section{KÖZÖS CSALÁDI ÉTKEZÉSEK}

A közös családi étkezések során szilárdul a családi egység és fokozódik az összetartozás érzése. Egy-egy családi étkezés, vacsora akár egy jóízű beszélgetés színtere is lehet. A mai rohanó világban szinte nincs egymásra ideje a családtagoknak. A rendszeres közös étkezés alkalom lehet arra, hogy minden nap beszélgessenek, ezzel közelebb kerülve egymáshoz, valamint az ilyen beszélgetések alkalmával a szülők a saját szokásaikat közvetíthetik a gyermekek felé, ezzel formálva a fiatalok egészségmagaratását, ezen belül is a táplálkozási szokásaikat. Serdülőkorban is a családnak van a legmeghatározóbb befolyása a gyermekek egészségére és életmódjára.

Bizonyított tény, hogy a rendszeres közös családi étkezések hatására a fiatalok egészségesebben táplálkoznak. (NÉMETH - KÖLTŐ, 2014) A diákok csupán hetede 
reggelizik minden nap legalább az egyik szülőjével és harmaduk hetente egyszer sem teszi ezt meg. Hasonló azok aránya, akik hetente 1-2-szer reggeliznek szülőikkel.

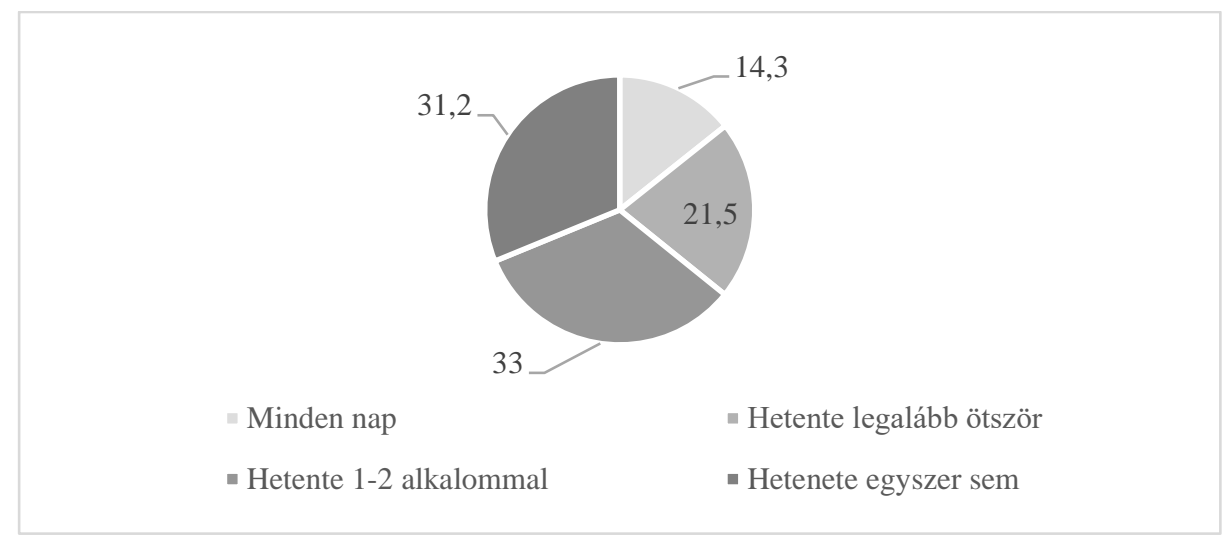

1. ábra: Közös reggelik aránya

Forrás: Saját szerkesztés

Ami a közös vacsorát illeti, csak minden harmadik diák vacsorázik együtt minden nap legalább az egyik szülőjével. A hetente legalább öt este együtt vacsorázók aránya 46,9\% és vannak, akik hetente egy este sem étkeznek együtt, ez körülbelül a diákok ötödére igaz. (NÉMETH - KÖLTŐ, 2014)

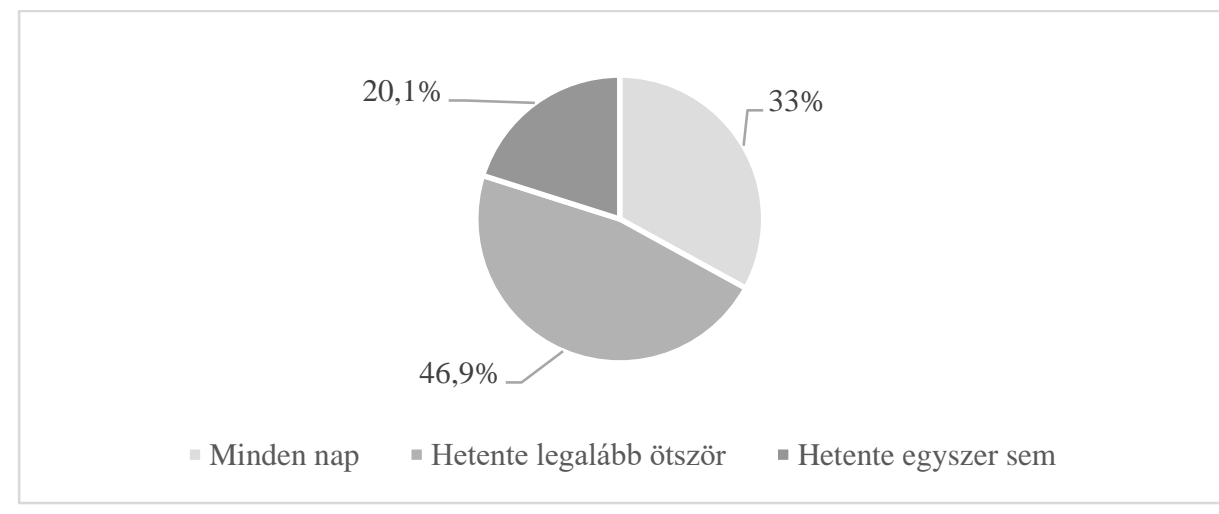

2. ábra: Közös vacsorák aránya Forrás: Saját szerkesztés

\section{TÁPLÁLKOZÁSI SZOKÁSOK}

Az étkezési szokások egyik legfontosabb tényezője a fóétkezések száma és rendszeressége. Serdülőkorban gyakori, hogy a fiatalok azért hagynak ki egy étkezést, mert nincs rá idejük. Ahogy azt fentebb is említettem, a középiskoláskorú diákok sokszor 
késő délutánig órán ülnek és közben nincs idejük beiktatni egy főétkezést, helyette esznek pár falatot, hogy kibírják az utolsó óra végéig, amikor hazamennek.

Máris kimaradt egy főétkezés. Ez az időhiány a reggelizési szokásokat is befolyásolja. A hétköznapokon, azaz, amikor reggelente, amikor a diákok iskolába sietnek, gyakrabban marad ki a reggeli, mint hétvégén, viszont hétvégén gyakoribb a „túlevés” és a nassolás. (PIKÓ - KERESZTES, 2008)

Egy 97 középiskolás bevonásával készült kutatás alapján a diákok 27\%-a soha és 44\%-a minden nap reggelizik hétköznap. Hétvégén a fiatalok 57\% reggelizik szombaton és vasárnap is. (SZABÓ - PIKÓ, 2017)

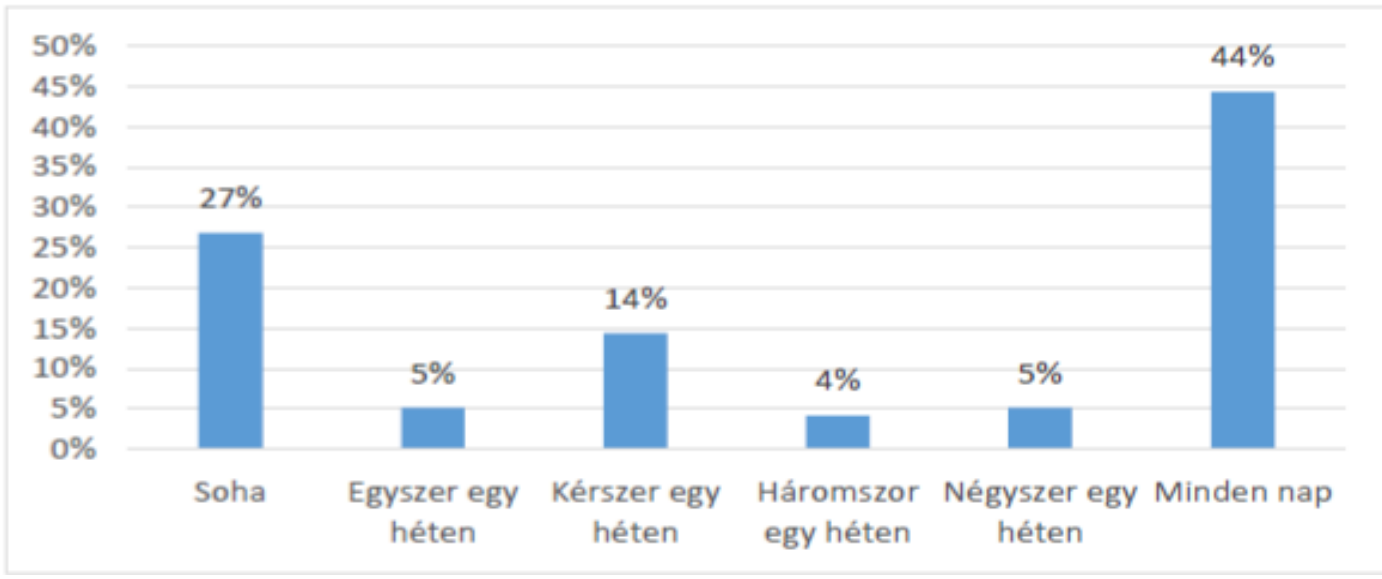

3. ábra: Reggelizés gyakorisága hétköznap

Forrás: Szabó Katalin, Pikó Bettina: Az étkezési magatartás összefüggése az ételválasztási motivációkkal és egyes személyiségbeli jellemzőkkel középiskolások körében, Egészségfejlesztés, LVIII. évfolyam, 2017. 2. szám

Hazánkban a serdülőkorban lévő fiatalok a nemzetközi átlagot el nem érő aránya szokott minden nap reggelizni, ez 48,3\%. (NÉMETH - KÖLTŐ, 2014) A másik fontos tényező az fóétkezések mennyisége mellett az étkezések minősége és változatossága. Mivel középiskolás korúakról van szó, figyelembe kell vennünk az erre a korosztályra jellemző túlzott optimizmust, amellyel kapcsolatban megállapították, hogy negatívan hat az egészséges táplálkozásra, ugyanis alul becsücsülhetik a helytelen táplálkozásból eredő betegségek kockázatát. (SZABÓ - PIKÓ, 2017)

\section{TÁPLÁLKOZÁSI ZAVAROK}

A nemzetközi átlagnak megfelelő a magyar fiatalok zöldség- és gyümölcs fogyasztása, sőt az elmúlt években a zöldség fogyasztás mértéke nőtt. Az elhízás és a kóros soványság is a helytelen táplálkozási szokásokra vezethető vissza. Sokan a súlyfeleslegüket a genetikai adottságaikra fogják, mintsem az étkezésükre vagy a mozgáshiányos életmódra. Hazánkra különösen jellemző, hogy magas az egészségtelen életmódból és helytelen táplálkozásból származó betegségek aránya, az elhízás és a vele járó magas vérnyomás vagy cukorbetegség. (FÜLÖP - SZAKÁLY, 2008) A fiatalok körében is megfigyelhető ez a tendencia, ugyanis a lányok 12\%-a és a fiúk 22\%-a túlsúlyos. A másik véglet sem 
elhanyagolható, ugyanis a 15-17 évesek körében, főleg a lányokra, de a fiúkra is jellemző a kóros soványság. A lányok negyede és a fiúk 17\%-a sovány. (KSH, 2015) Sokszor a soványságot a genetikai tényezők mellett, túlzott diétázás, testképzavarok és étkezési zavarok okozhatják.

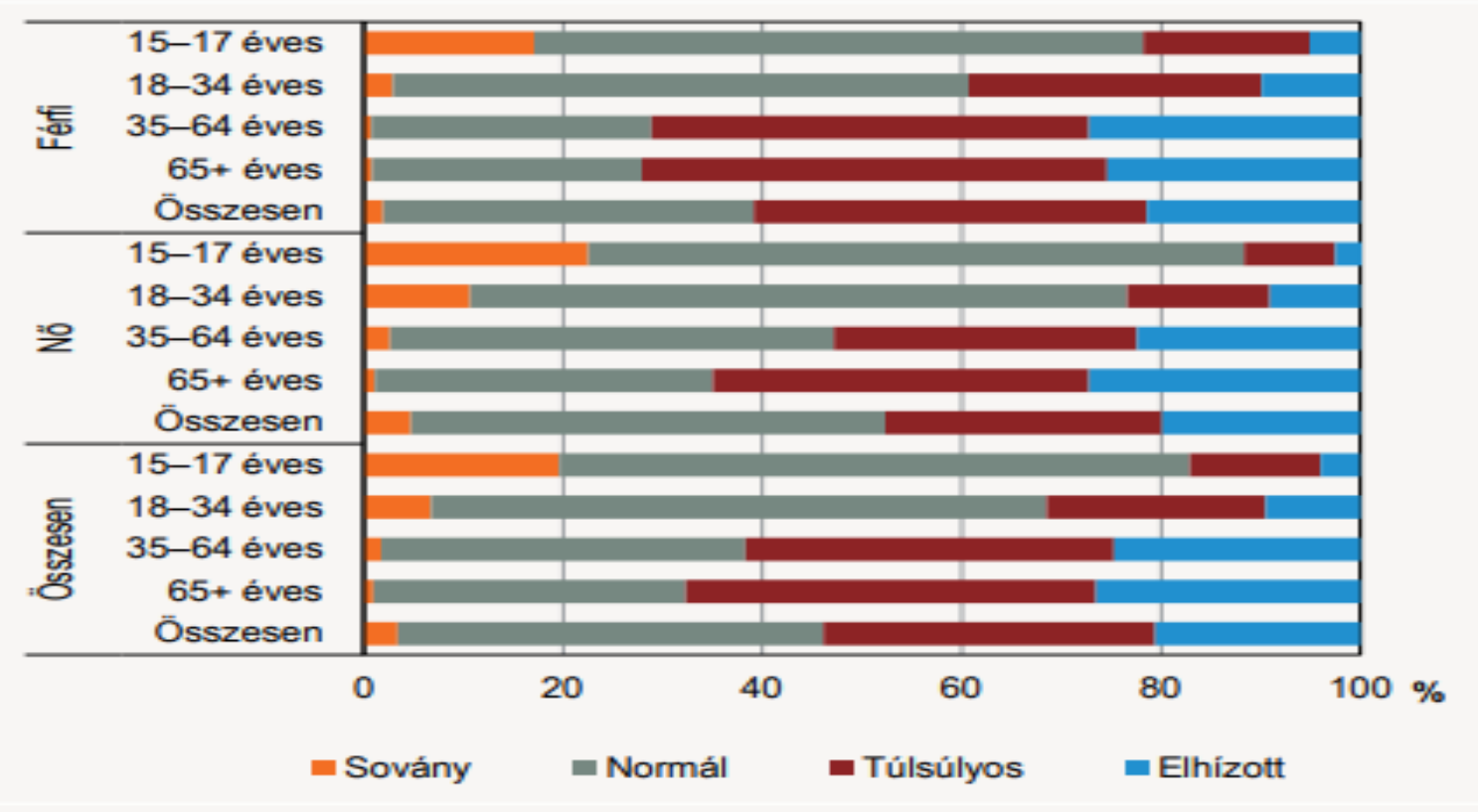

4. ábra: Testtömegindex-kategóriák nemenként és korcsoportonként

Forrás: KSH (2015)

\section{KÖZÖSSÉGI MÉDIA HATÁSA}

Manapság minden serdülókorú fiatal rendelkezik okos telefonnal és internet elérhetőséggel. A társadalmi szokásokhoz híven legnagyobb részük jelen van valamilyen internetes közösségi felületen (Facebook, Instagram), ahol a nap 24 órájában csevegnek, képeket, videókat, fájlokat osztanak meg egymással. Egyre divatosabb posztolni, hogy ki mit csinál éppen, hova utazott, kivel van, és hogy mit eszik. Rengeteg ételről szóló oldal, poszt és \# található az interneten. Vannak kifejezetten egészséges- vagy gyorsételekről szóló oldalak a közösségi médiában, és a felhasználók előszeretettel jelölik meg az ételfotóik alatt a \#healthyfood hashtaget. Jelenleg 86,6 M bejegyzés alatt látható. Ebben is látszik, hogy sokan fontosnak tarják, hogy egészségesen táplálkozzanak. A közösségi médiában megosztott egészséges ételről szóló tartalmak összessége kimeríthetetlen ötletforrás lehet azok számára, akik egészségesen szeretnének táplálkozni. (PETŐ et al.,2017). 


\section{KORTÁRSAK HATÁSA}

A diákok az idejük túlnyomó részét az iskola és a délutáni elfoglaltságok, például edzések miatt kortársaikkal töltik. Serdülőkorban a szülőktől való függetlenedés során a kamaszok inkább a kortársaikra vagy barátaikra hallgatnak, még a fontosabb kérdésekben is. Ilyen a táplálkozás is. Délután, iskola után gyakran látni kisebb, nagyobb csoportokban középiskolás korúakat neves gyorséttermekben. Ez egyfajta közösségi program is számukra, amely során megbeszélhetik az aktuális szerelmi életüket, problémáikat és az éppen aktuális témáikat. Ha valaki nem tart velük, mert például hazamegy ebédelni, akkor hamar kiközösítik a baráti körből a közös program gyakori kihagyása miatt. Ez a kortársnyomás nagyban befolyásolja a fiatalok egészségmagatartását. Próbálnak megfelelni az aktuális trendeknek és a kortársaik elvárásainak. Ez a nyomásnak akár pozitív hatása is lehet. Egy olyan osztályban vagy közösségben, ahol a legtöbben egészségesen étkeznek és egészséges életmódot élnek, szinte kellemetlenül érzi magát a diák, ha nem felel meg kortársai ezen elvárásainak. Bár korábbi kutatások azt igazolják, hogy a szülők és kortársak befolyását összehasonlítva, sokkal erőteljesebbnek találták a család szerepét, mint a barátokét, de közvetetten mégis nagy befolyással bírnak a kortársak az étkezési szokásokra. (PIKÓ - KERESZTES, 2008) A középiskolás korú serdülők testsúllyal, testképpel kapcsolatos vélekedéseire azonban nagy hatással vannak a kortársak. A kívánatosnak tartott testkép kihat az ételválasztásra és az ételek rangsorára is. Ennek hatására gyakori, fóleg a lányok körében a barátok között végig vonuló diétahullám. (PIKÓ - KERESZTES, 2008) A serdülő lányok az előbb említett okok miatt sokat foglalkoznak kinézetükkel. Körükben egyre gyakoribb a táplálkozási zavarok kialakulása, ilyen például az Anorexia Nervosa (AN). Egy kutatásban kimutatták a 15-24 éves nők országos reprezentatív mintáján, hogy a fiatal nők 23\%-ának magas a karcsúság iránti késztetése és közel egytizedüknek nem éri el az AN küszöbnek számító 17,5-es értéket a testtömeg-indexe. (SUSÁNSZKY - SZÁNTÓ, 2008)

\section{MEGBESZÉLÉS}

Célom az volt, hogy feltárjam a lehetséges beavatkozási területeket, a fiatalok egészséges életmódra nevelésében. A középiskolás korúakat legjobban az interneten, ezen belül is a közösségi felületeken lehet elérni, így elsősorban ezen a felületen lenne érdemes egészséges életmódra nevelő programokat létrehozni számukra. A másik lehetséges helyszín erre az iskola, mivel itt töltik idejük legnagyobb részét a diákok. A gyakori egészséges életmóddal kapcsolatos iskolai programokkal vagy az iskolabüfé kínálatának egészségesebbé tételével lehetne ösztönözni a fiatalokat az egészséges táplálkozásra

A publikáció elkészültét az EFOP-3.6.1-16-2016-00022 „Debrecen Venture Catapult Program" projekt támogatta. A projekt az Európai Unió támogatásával, az Európai Szociális Alap társfinanszírozásával valósult meg. 


\section{IRODALOMJEGYZÉK}

Fülöp N., Szakály Z. (2008). Fiatalok táplálkozási szokásai, egészségmagatartása szekunder kutatás. Élelmiszer Táplálkozás és Marketing, 5, (1), 81-6.

Kaposvári J. (2007). Az iskolai egészségnevelési és környezetnevelési programok megvalósulása a 2004-2005-ös tanévben

Központi Statisztikai Hivatal (2015). Európai lakossági egészségfelmérés, 2014. Statisztikai Tükör, 29.

Németh Á., Költő A. (szerk).(2014). Egészség és egészségmagatartás iskoláskorban. Az Iskoláskorú gyermekek egészségmagatartása elnevezésű, az Egészségügyi Világszervezettel együttműködésben megvalósuló nemzetközi kutatás 2014. évi felméréséről készült nemzeti jelentés. Nemzeti Egészségfejlesztési Intézet, Budapest, 1831.

Neumark-Sztainer D., Story M., Perr C., \& Casey M.A. (1999). Factors influencing choices of adolescents: Findings from focus-group discussions with adolescents. Journal of the American Dietetic Association, 99, 929-934.

Pető D., Prónay Sz., \& Buzás N. (2017). A közösségi média hatása a fiatalok táplálkozási szokásaira.

Pikó B., Keresztes N. (2008): Középiskolás fiatalok étkezési szokásai és ezek hatása a saját táplálkozási magatartás megítélésére. Egészségfejlesztés, 49, (1-2), 9-15.

Pikó B., Keresztes N. (2008). Táplálkozáskontroll középiskolások körében, Mentálhigiéné és Pszichoszomatika, 9, (2), 149-164.

Ságodi L., Sólyom E., \& Kiss-Tóth E. (2017). A csecsemőkori táplálás összefüggése a gyermekkori elhízással, Orvosi Hetilap; 158, (24), 938-943.

Susánszky É., Szántó Zs. (2008). Ifjúság és egészség; Ifjúságszemléleti folyóirat VI. évfolyam, 2. szám (2008)

Szabó K., Pikó B. (2017). Az étkezési magatartás összefüggése az ételválasztási motivációkkal és egyes személyiségbeli jellemzőkkel középiskolások körében, Egészségfejlesztés, LVIII. évfolyam, 2017. 2. szám 
Vol 3, No 2 (2020): Stadium-Hungarian Journal of Sport Sciences https://doi.org/10.36439/SHJS/2020/2/8598 